\title{
Rola Parlamentu Europejskiego w procesie ksztaltowania Wspólnej Polityki Zagranicznej i Bezpieczeństwa UE po zawarciu Traktatu z Lizbony
}

\section{Ustanowienie Wspólnej Polityki Zagranicznej i Bezpieczeństwa UE}

Upadek projektu powołania Europejskiej Wspólnoty Obronnej ${ }^{1}$ i zaprzestanie prac nad utworzeniem unii politycznej oznaczały nadanie zainicjowanemu po II wojnie światowej procesowi integracji europejskiej przede wszystkim charakteru współpracy gospodarczej ${ }^{2}$.

Zarzucenie w latach 50-tych XX w. realizacji idei jedności politycznej Europy Zachodniej, a także sprzeczności między państwami członkowskimi Europejskiej Wspólnoty Gospodarczej (EWG) co do zasadniczych cech przyszłej unii politycznej zdecydowały o rezygnacji z bardziej ambitnych koncepcji integracyjnych i skupienie się na rozwiązaniach minimalistycznych, a zarazem bardziej pragmatycznych, do których zaliczono kwestie koordynacji polityk zagranicznych państw Wspólnoty. Taki pogląd znalazł odzwierciedlenie w ustanowieniu w 1970 r. Europejskiej Współpracy Politycznej (EWP) jako pozatraktatowej formy uzgadniania stanowisk i podejmowania wspólnych akcji dyplomatycznych przez państwa tworzące Wspólnoty Europejskie. Dopiero wejście w życie 1 lipca 1987 r. Jednolitego Aktu Europejskiego spowodowało włączenie EWP w ramy prawno-traktatowe Wspólnot. Nie zapewniło to jednak, głównie

1 Stanowisko USA w kwestii remilitaryzacji Niemiec Zachodnich zakładające przystapienie tego kraju do NATO skłoniło Francję do opracowania własnego projektu włączenia RFN do zachodniego systemu bezpieczeństwa. Inicjatywa ta znalazła wyraz w planie autorstwa ówczesnego premiera Francji R. Plevena przedstawionym Zgromadzeniu Narodowym 24 października 1950 r., zakładającym utworzenie ponadnarodowej Europejskiej Wspólnoty Obronnej (EWO). Jej filarem miało być powołanie zintegrowanej, mieszanej narodowościowo armii europejskiej, podporządkowanej instytucjom zjednoczonej Europy. Układ ustanawiający EWO, który został podpisany 27 maja 1952 r. w Paryżu był wzorowany na zawartym rok wcześniej traktacie powołującym Europejską Wspólnotę Węgla i Stali. Zakładał on powołanie organizacji, w ramach której wykorzystywane miały zostać mechanizmy współpracy ponadnarodowej, co oznaczało częściowe zrzeczenie się przez państwa członkowskie suwerenności w dziedzinie bezpieczeństwa i obrony na rzecz wspólnotowych instytucji europejskich. Ostatecznie Układ o EWO nie wszedł w życie wskutek odmowy ratyfikacji przez francuskie Zgromadzenie Narodowe, co pogrzebało na dziesiątki lat ponadnarodową koncepcję integracji polityczno-militarnej Europy (por. szerzej: Romaniuk-Całkowska, 2004, s. 46-56; Wiaderny-Bidzińska, 2002, s. 70-84).

2 Powstała na mocy podpisanych 25 marca 1957 r. traktatów rzymskich Europejska Wspólnota Gospodarcza za strategiczny cel stawiała sobie ustanowienie wspólnego rynku i stopniową harmonizację polityk gospodarczych państw członkowskich, nie zakładając podjęcia kroków integracyjnych w dziedzinie współpracy politycznej. 
wskutek braku woli politycznej państw członkowskich, jak i niskiego poziomu instytucjonalizacji EWP, zacieśnienia i pogłębienia współpracy krajów Wspólnoty w dziedzinie polityki zagranicznej. Dopiero przyśpieszenie procesu integracji gospodarczej, któremu towarzyszyły zmiany ustrojowe w krajach Europy Środkowo-Wschodniej wymogły na państwach członkowskich Wspólnot Europejskich podjęcie prób wypracowania bardziej spójnej i skutecznej polityki zagranicznej i bezpieczeństwa funkcjonującej w ramach tworzącej się Unii Europejskiej (Zięba, 2005, s. 11).

Ostateczne porozumienie w kwestii zawarcia Traktatu o Unii Europejskiej (TUE) zostało osiagnięte na szczycie Rady Europejskiej, który miał miejsce 9-10 grudnia 1991 r. w Maastricht. Oficjalnie TUE został podpisany 7 lutego 1992 r., a wszedł w życie z dniem 1 listopada 1993 roku. Ustanowił on Unię Europejską jako strukturę trójfilarową o charakterze hybrydowym i niedookreślonym łączącą w sobie mechanizmy współpracy ponadnarodowej i międzyrządowej. Traktat z Maastricht nie ustanowił więc unii politycznej, gdyż wskutek rozbieżnych stanowisk państw członkowskich nie rozstrzygnął najważniejszych kwestii odnoszących się do procesu integracji europejskiej takich jak między innymi zdefiniowanie celu integracyjnego, do realizacji którego powinna dążyć Unia. Nie rozstrzygnięto więc zasadniczego dylematu, a mianowicie czy Unia ma w przyszłości stać się federacją czy pozostać organizacją międzynarodową, w ramach której decydującą rolę będą odgrywać państwa narodowe (por. Świętochowska, 2002, s. 23-24).

Tą specyfikę UE odzwierciedlała umiejscowiona w II filarze Wspólna Polityka Zagraniczna i Bezpieczeństwa (WPZiB), której kwestie uregulowano w Tytule V TUE. WPZiB będąc węższym segmentem szeroko pojętych stosunków zewnętrznych UE była i jest do dnia dzisiejszego regulowana głównie przez mechanizmy współpracy międzyrządowej. Natomiast drugi komponent polityki zewnętrznej UE, czyli stosunki zewnętrzne o charakterze ekonomicznym, określane mianem wspólnotowej polityki zagranicznej podlegały w głównej mierze kompetencjom wspólnotowym (por. Zięba, 2003, s. 37-61).

Ustanowienie WPZiB nie oznaczało, że państwa członkowskie UE wyrzekły się posiadanych narzędzi realizacji swoich interesów narodowych. Prowadziło to często do braku efektywności działania UE na arenie międzynarodowej i niemożliwości skutecznego rozwiązywania konfliktów w swoim otoczeniu (konflikt bałkański w latach 90-tych XX w.), gdyż często największe kraje UE, posiadając jasno sprecyzowane interesy międzynarodowe i dysponując instrumentami ich realizacji, przedkładały egoistycznie pojmowaną rację stanu nad wypracowanie wspólnego stanowiska całej UE. Ponadto UE realizując po Traktacie z Maastricht politykę zagraniczną dysponowała znacznie silniejszym niż w przypadku WPZiB zestawem środków tworzonych od wielu dziesięcioleci w ramach Wspólnot Europejskich jak np. umowy stowarzyszeniowe, umowy o współpracy i partnerstwie, układy o preferencyjnym handlu, które umiejscowione w I filarze zawierają mniejszy lub większy komponent polityczny (Turczyński, 2007, s. 43).

Sytuacja ta powodowała, że mimo nazwy sugerującej „,uwspólnotowienie”, WPZiB była najsłabszym komponentem UE, który w przeciwieństwie do wspólnotowego charakteru I filaru stanowił przede wszystkim międzyrządowy instrument współpracy państw członkowskich ${ }^{3}$.

3 W II filarze UE procesy integracyjne przebiegały zgodnie z międzyrządową metodą integracji. Zakłada ona, że w procesie integracji europejskiej dominująca rola powinna przypadać państwu naro- 


\section{Reforma WPZiB w Traktacie z Lizbony}

Słabość ustanowionej w Maastricht WPZiB, którą możemy zdefiniować jako zinstytucjonalizowany system współpracy państw członkowskich UE w dziedzinie polityki międzynarodowej spowodowała, że w kolejnych nowelach traktatowych z Amsterdamu i Nicei podjęto próbę jej większego uwspólnotowienia. Próby te mimo włączenia do obszaru WPZiB pewnych nielicznych mechanizmów współpracy ponadnarodowej nie powiodła się. W praktyce politycznej w podejściu do WPZiB dominowało myślenie w kategoriach interesu narodowego, co utrudniało tworzenie przez Unię realnej tożsamości międzynarodowej i opóźniało proces budowy Europy jako zintegrowanej struktury politycznej zdolnej kształtować politykę zagraniczną opartą na mechanizmach współpracy ponadnarodowej. Oznaczało to, że wspólnotowość WPZiB pozostawała w sferze postulatywnej, stanowiąc dość labilny kompromis pomiędzy suwerennością państw tworzących UE a ich integracyjną retoryką (Łoś-Nowak, 2005, s. 7-9).

Ostatnia i najważniejsza reforma WPZiB miała miejsce wraz z wejściem w życie Traktatu z Lizbony, który zlikwidował Wspólnotę Europejską (inkorporacja do UE) i nadał osobowość prawną UE. Likwidacja filarowej struktury UE spowodowała, że stała się ona jednolitą organizacją międzynarodową jednakże w jej ramach utrzymano szczególny charakter WPZiB jako polityki w przeważającej mierze międzyrządowej. W deklaracjach przyjętych przez Konferencję Międzyrządową, która zatwierdziła Traktat z Lizbony, stwierdzono wprost, że postanowienia TUE odnoszące się do WPZiB nie naruszają odpowiedzialności państw członkowskich za kształtowanie i prowadzenie własnej polityki zagranicznej ani sposobu, w jaki są one reprezentowane w państwach trzecich i organizacjach międzynarodowych. Ponadto w dokumentach tych podkreślono, że postanowienia regulujące WPZiB, jak i stanowiącą jej integralną część Wspólną Politykę Bezpieczeństwa i Obrony (WPBiO) nie naruszają jej szczególnego charakteru. Odnotowano również, że Komisja Europejska (KE) w dziedzinie WPZiB nie otrzyma nowych uprawnień do inicjowania decyzji ani nie zwiększy się rola Parlamentu Europejskiego (PE) w tym obszarze integracji (zob. Deklaracje dołączone do Aktu Końcowego Konferencji Międzyrządowej, która przyjęła Traktat z Lizbony podpisany w dniu 13 grudnia 2007).

Brak istotnych uprawnień decyzyjnych dla organów UE o ponadnarodowym statusie ustrojowym (KE, PE, Europejski Trybunał Sprawiedliwości - ETS) znalazło odzwierciedlenie $\mathrm{w}$ zreformowanym TUE, w którym utrzymano $\mathrm{w}$ obszarze WPZiB dominację mechanizmów współpracy międzyrządowej nad ponadnarodowym podejściem, co najpełniej znalazło wyraz w art. 24 ust. 1 Tytułu 5 TUE. Potwierdzono w nim, że WPZiB podlega szczególnym zasadom i procedurom i jest określana oraz realizo-

dowemu reprezentowanemu przez suwerenny rząd. Podkreśla się, że państwa są równymi partnerami $\mathrm{w}$ tym procesie posiadającymi prawo weta i zachowującymi swoje kompetencje władcze. Transfer tych kompetencji na rzecz instytucji ponadnarodowych nawet jeśli ma miejsce ma charakter szczątkowy. Instytucje te nie powinny stanowić centrów decyzyjnych, a jedynie pełnić rolę organów doradczo-konsultacyjnych. Zgodnie z logiką tej metody decydujące znaczenie w ramach UE winna mieć Rada UE jako organ o międzyrządowym statusie ustrojowym, natomiast rola organów ponadnarodowych takich jak Komisja Europejska czy Parlament Europejski powinna być mniej znacząca (Ruszkowski, 2007, s. 177-178; por. szerzej: Cini, 2007, s. 139-161). 
wana przez organy o statusie ustrojowym międzyrządowym tj. Radę Europejską i Radę stanowiące z pewnymi wyjątkami jednomyślnie. Ponadto wykluczono przyjmowanie w obszarze WPZiB aktów ustawodawczych. Kompetencje Unii w zakresie WPZiB określono jako obejmujące wszelkie dziedziny polityki zagranicznej i ogół kwestii dotyczących bezpieczeństwa Unii, w tym stopniowe określanie wspólnej polityki obronnej, która może (ale nie musi) prowadzić do wspólnej obrony. Wykonanie WPZiB powierzono Wysokiemu Przedstawicielowi Unii ds. Spraw Zagranicznych i Polityki Bezpieczeństwa oraz państwom członkowskim (Wersja skonsolidowana Traktatu o Unii Europejskiej).

Ustanowienie urzędu Wysokiego Przedstawiciela należało do najważniejszych reform instytucjonalnych WPZiB przyjętych w Traktacie z Lizbony. Urząd ten będący namiastką ,ministra spraw zagranicznych Unii” łączy w sobie funkcje sprawowane do zawarcia Traktatu z Lizbony przez wysokiego przedstawiciela ds. WPZiB oraz komisarza KE ds. stosunków zewnętrznych Unii. Połączenie obu funkcji w jednym urzędzie zlikwidowało dualizm władzy nad unijną polityką zagraniczną, gdyż nowy wysoki przedstawiciel objął również funkcję wiceprzewodniczącego KE, co oznaczało pojawienie się nowego elementu uwspólnotowienia WPZiB (zob. szerzej: Miszczak, 2008, s. 243-248).

Zlikwidowanie dualizmu władzy nad unijną polityką zagraniczną nie spowodowało jednakże ustanowienia jednolitych stosunków zewnętrznych UE, gdyż Traktat z Lizbony zachował odrębność i szczególny charakter WPZiB w stosunku do pozostałych obszarów działania Unii, potwierdzając jej międzyrządowy charakter. Ponadto dualizm stosunków zewnętrznych UE został usankcjonowany przez obowiązujący w UE porządek traktatowy. Kwestie polityki zagranicznej UE regulowane są nie tylko przez Tytuł V TUE (regulacje odnoszące się do WPZiB), ale również przez Traktat o Funkcjonowaniu UE (TFU), którego postanowienia odnoszą się do wspólnej polityki handlowej, współpracy z państwami trzecimi i pomocy humanitarnej. Oznacza to, że de facto polityka zagraniczna UE wciąż mimo pewnego osłabienia pozostaje dwufilarowa, gdyż zachowane zostały odrębności pomiędzy WPZiB a działaniami zewnętrznymi dotychczasowego I filara (por. Jarecki, 2010).

\section{Kompetencje Parlamentu Europejskiego w dziedzinie WPZiB i całości stosunków zewnętrznych UE}

Zachowanie faktycznej dwufilarowości stosunków zewnętrznych UE przy ustanowieniu UE jako jednolitej organizacji międzynarodowej powoduje, że po Traktacie z Lizbony rola PE jako organu unijnego o statusie ustrojowym ponadnarodowym w kształtowaniu WPZiB nie jest łatwa do zdefiniowania. Pozycja PE w obszarze WPZiB została określona przez art. 36 TUE, który stanowi, że: „Wysoki przedstawiciel Unii... regularnie konsultuje się z Parlamentem Europejskim w zakresie głównych aspektów i podstawowych opcji wspólnej polityki zagranicznej i bezpieczeństwa oraz wspólnej polityki bezpieczeństwa i obrony, oraz informuje Parlament Europejski o rozwoju tych polityk. Czuwa on nad tym, aby poglądy Parlamentu Europejskiego zostały należycie uwzględnione. Specjalni przedstawiciele mogą uczestniczyć w informowa- 
niu Parlamentu Europejskiego. Parlament Europejski może kierować do Rady i do wysokiego przedstawiciela pytania lub formułować pod ich adresem zalecenia. Dwa razy w roku przeprowadza on debatę o postępach w realizacji wspólnej polityki zagranicznej i bezpieczeństwa, w tym wspólnej polityki bezpieczeństwa i obrony" (Wersja skonsolidowana Traktatu o Unii...). Artykuł ten ze względu na międzyrządowy charakter WPZiB nie przyznaje PE istotnych kompetencji władczych. Taki zakres traktatowych kompetencji oznacza, że PE nie ma formalnego wpływu na kształt przyjmowanych w ramach WPZiB aktów prawnych tj. decyzji. Są one podejmowane przez Radę Europejską i Radę UE niemal wyłącznie jednomyślnie i nie mają charakteru prawodawczego ${ }^{4}$.

Parlament nie jest również organem współdecydującym w kwestiach mianowania specjalnych przedstawicieli UE. Natomiast po Traktacie z Lizbony poszerzeniu uległy kompetencje PE w kwestii powoływania Wysokiego Przedstawiciela Unii ds. Zagranicznych i Polityki Bezpieczeństwa, który jest mianowany przez Radę Europejską, stanowiącą większością kwalifikowaną i za zgodą przewodniczącego KE. Przez fakt bycia jednym $\mathrm{z}$ wiceprzewodniczących KE, wysoki przedstawiciel razem z przewodniczącym i innymi członkami KE podlega zatwierdzeniu w drodze głosowania przez PE. Ponadto TUE stanowi, że w przypadku uchwalenia przez PE wotum nieufności w stosunku do kolegium KE, wysoki przedstawiciel musi zrezygnować ze swojej funkcji pełnionej w ramach Komisji. Jednakże pełni on nadal swoje obowiązi w ramach Rady UE do czasu powołania nowego składu KE (zob. Wysoki Przedstawiciel Unii do Spraw Zagranicznych i Polityki Bezpieczeństwa).

Istotne kompetencje decyzyjne posiada natomiast PE w kwestii finansowania WPZIB, co jest związane z posiadaniem przez ten organ szerokich prerogatyw budżetowych. Już w Traktacie z Maastricht w celu zachowania międzyrządowego charakteru WPZiB jej wydatki budżetowe podzielono na wydatki administracyjne pokrywane z budżetu wspólnotowego oraz operacyjne finansowane z budżetu wspólnotowego albo przez państwa członkowskie na podstawie decyzji Rady podjętej jednomyślnie. Sytuacja taka powodowała wiele komplikacji dlatego Traktat Amsterdamski ustanowił generalną zasadę, że wydatki operacyjne finansowane są z budżetu unijnego z wyjątkiem zadań petersberskich o militarnym charakterze oraz w przypadku, gdy Rada UE w wyniku jednomyślnego głosowania ustali odmienne reguły finansowania (Czubocha, Paszkowska).

W związku ze zmianami finansowania WPZiB Parlament Europejski podjął próbę uzyskania większego wpływu na wydatkowanie środków na działania operacyjne poprzez każdorazowe udzielanie zgody na ich finansowanie. Spotkało się to jednak ze zdecydowanym oporem państw członkowskich strzegących międzyrządowego charakteru II filarus.

${ }^{4}$ Zgodnie z art. 25 TUE Unia prowadzi wspólną politykę zagraniczną i bezpieczeństwa poprzez: określanie ogólnych wytycznych, przyjmowanie decyzji określających działania i stanowiska, które powinny być prowadzone przez Unię, zasady wykonania decyzji, umacnianie systematycznej współpracy między Państwami Członkowskimi w prowadzeniu ich polityki (Wersja skonsolidowana Traktatu $o$ Unii...).

${ }^{5}$ Ibidem. Należy podkreślić, że środki budżetowe przeznaczone na WPZiB są niewielkie i dlatego część wydatków jest pokrywana bezpośrednio z budżetów państw członkowskich. O ile wydatki operacyjne cywilnych misji petersberskich (misje policyjne, doradcze) są pokrywane z budżetu wspól- 
Ustrukturyzowany dialog między Radą UE a PE w kwestii finansowania WPZiB przewidywało porozumienie międzyinstytucjonalne z dnia 17 maja $2006 \mathrm{r}$. Zgodnie z jego literą, instytucje wspólnotowe (Rada, PE, KE) miały dążyć do osiągnięcia każdego roku porozumienia $\mathrm{w}$ sprawie kwoty wydatków operacyjnych ponoszonych z budżetu Wspólnoty zgadzając się, że w latach 2007-2013 na WPZiB przeznaczone zostanie co najmniej 1740 milionów EUR. Porozumienie to ustanowiło również regularne spotkania konsultacyjne pomiędzy PE a prezydencją Rady odnoszące się do dokumentu perspektywicznego Rady określającego główne aspekty i podstawowe wybory w zakresie WPZiB, łącznie ze skutkami finansowymi dla budżetu ogólnego UE. Ponadto w wyniku porozumienia prezydencja Rady została zobligowana do regularnego informowania PE, odbywając co najmniej pięć razy w roku wspólne spotkania konsultacyjne w ramach stałego dialogu politycznego w sprawie WPZIB (zob. Porozumienie międzyinstytucjonalne pomiędzy Parlamentem Europejskim, Radq $i$ Komisja w sprawie dyscypliny budżetowej i należytego zarzadzania finansami).

Prerogatywy budżetowe PE w dziedzinie WPZiB po wejściu w życie Traktatu z Lizbony zostały określone w nowym art. 41 TUE, który stanowi, że zarówno wydatki administracyjne związane z realizacją WPZiB, jak również wydatki operacyjne, $\mathrm{z}$ wyjątkiem wydatków przypadających na operacje mające wpływ na kwestie wojskowe i polityczno-obronne (finansowane są one przez państwa członkowskie) są pokrywane z budżetu UE. Oznacza to, że wydatki UE na realizację misji cywilnych lub cywilnych aspektów operacji wojskowych, podlegają kontroli PE. Natomiast w przypadku konieczności przyjęcia przez Radę UE decyzji ustanawiającej szczególne procedury w celu zagwarantowania szybkiego dostępu do środków budżetowych UE przeznaczonych na natychmiastowe finansowanie inicjatyw w ramach WPZiB zobligowana jest ona do konsultacji z PE (Wersja skonsolidowana Traktatu o Unii...).

Kompetencje budżetowe PE nie mogą przesłonić faktu, że z prawno-traktatowego punktu widzenia rola tego organu w kształtowaniu WPZiB jest bardziej niż skromna i sprowadza się do odgrywania roli instytucji o charakterze konsultacyjno-opiniodawczym, która co najwyżej jest informowana o przebiegu prac nad kształtem i rozwojem WPZiB. Jednakże w praktyce funkcjonowania WPZiB oddziaływanie PE na jej kształt jest znacznie większe. Należy podkreślić, że WPZiB jest jedynie częścią szeroko pojętych stosunków zewnętrznych UE, a istotną ich treść stanowią zagadnienia wchodzące, do wejścia w życie Traktatu Lizbońskiego, w zakres tzw. wspólnotowej polityki zagranicznej, funkcjonującej w przeszłości w ramach I filaru. Podmiotem odpowiedzialnym za realizację tej polityki była Wspólnota Europejska (WE), a polityka ta była często określana mianem ekonomicznych stosunków zewnętrznych, które regulowane były przez Traktat o Wspólnocie Europejskiej (TWE). Po zmianach dokonanych przez Traktat Lizboński kwestie te regulowane są przez Traktat o Funkcjonowaniu UE (TFUE). Rola PE w tym obszarze polityki zagranicznej UE polega przede wszystkim na uczestniczeniu w procesie zawierania umów międzynarodowych ${ }^{6}$. Bardzo istotną

notowego, to koszty militarnych zadań petersberskich (operacje utrzymania pokoju, siłowego rozwiązywania kryzysów) ponoszone są przez państwa członkowskie (Kurczewska, 2005).

${ }^{6}$ Zgodnie $\mathrm{z}$ art. 218 decyzję w sprawie zawarcia umowy międzynarodowej podejmuje Rada UE. Z wyjątkiem przypadków gdy umowy dotyczą wyłącznie WPZiB, Rada UE przyjmuje decyzję 
prerogatywą PE w dziedzinie całości stosunków zewnętrznych UE jest również wyrażanie przez ten organ na podstawie art. 49 TUE zgody na przystapienie nowych państw do Unii ${ }^{7}$.

Oprócz uczestniczenia w zawieraniu umów międzynarodowych, PE może wpływać na kształtowanie polityki zewnętrznej UE poprzez utrzymywanie stosunków z parlamentami krajów nienależących do Unii. Zgodnie z Regulaminem PE może on powoływać wspólne komisje parlamentarne z parlamentami państw stowarzyszonych z UE lub parlamentami państw, z którymi zostały rozpoczęte negocjacje akcesyjne. Komisje te mogą sporządzać zalecenia pod adresem reprezentowanych w nich parlamentów, a ich zakres kompetencji jest określany przez PE oraz umowy z państwami trzecimi (Regulamin..., art. 200).

Istotnym uprawnieniem PE w dziedzinie dawnej wspólnotowej polityki zagranicznej jest również współkreowanie z Radą UE i KE współpracy gospodarczej, finansowej i technicznej z państwami trzecimi poprzez tworzenie wieloletnich programów służących rozwojowi krajów biedniejszych i ich włączaniu w struktury światowej gospodarki. W tym celu utworzony został jeden pomocowy instrument finansowy, który zastapił adresowany do krajów południowego wybrzeża Morza Śródziemnego program MEDA i program TACIS ukierunkowany na państwa byłego Związku Radzieckiego. W październiku 2006 r. PE i Rada UE, stanowiąc zgodnie z obowiązująca wówczas procedurą współdecydowania, zastąpioną po Traktacie Lizbońskim przez zwykłą procedurę prawodawczą, przyjęły rozporządzenie ustanawiające jednolity Europejski Instrument Sąsiedztwa i Partnerstwa w celu świadczenia pomocy wspólnotowej dla państw sąsiedzkich UE (zob. Rozporzadzenie (WE) $n$ r 1638/2006 Parlamentu Europejskiego i Rady z dnia 24 października 2006 r. określajace przepisy ogólne w sprawie ustanowienia Europejskiego Instrumentu Sasiedztwa i Partnerstwa, s. 1-13).

w sprawie zawarcia umowy po uzyskaniu zgody PE w przypadku między innymi umów stowarzyszeniowych, umowy dotyczącej przystapienia Unii do europejskiej Konwencji o ochronie praw człowieka i podstawowych wolności, umów mających istotne skutki budżetowe dla Unii, umów dotyczących dziedzin, do których stosuje się zwykłą procedurę prawodawczą lub specjalną procedurę prawodawczą, jeżeli wymagana jest zgoda PE. W innych przypadkach umowa jest zawierana przez Radę UE po konsultacji z PE (zob. Wersja skonsolidowana Traktatu o Funkcjonowaniu Unii Europejskiej).

W procesie akcesji do UE, PE odgrywa istotną rolę. Na wniosek właściwej komisji, grupy politycznej, co najmniej 40 posłów Parlament może zwrócić się do KE lub Rady UE o udział w debacie przed rozpoczęciem negocjacji z państwem kandydującym. Wniosek państwa europejskiego o przystąpienie do UE jest przekazywany do rozpatrzenia właściwej komisji parlamentarnej, która jest regularnie informowana przez Radę i Komisję o postępach w procesie negocjacji. W każdym stadium negocjacji Parlament może uchwalać zalecenia i domagać się ich uwzględnienia przed zawarciem traktatu akcesyjnego. Po zakończeniu negocjacji, ale przed zawarciem traktatu akcesyjnego, projekt umowy przedstawia się PE, który na podstawie raportu właściwej komisji, większością głosów wyraża zgodę na przystąpienie państwa kandydującego do UE (zob. Regulamin Parlamentu Europejskiego, art. $74 \mathrm{c})$. 


\section{Parlament Europejski jako instytucja wpływu politycznego w obszarze WPZiB}

Powyższe kompetencje PE w dziedzinie stosunków zewnętrznych UE nabierają w odniesieniu do WPZiB istotnego znaczenia, zwłaszcza po wejściu w życie Traktatu Lizbońskiego. Ustanowienie jednolitej polityki zagranicznej UE, choć z zachowaniem odrębności WPZiB, zachęciło PE do rozszerzania formalnie przysługujących tej instytucji uprawnień. Będąc jedynym organem UE mającym demokratyczną legitymację, PE wykazuje dużą aktywność w dziedzinie sprawowania demokratycznej kontroli nad WPZiB. Brak kompetencji decyzyjnych w obszarze WPZiB nie przeszkadza PE w odgrywaniu roli instytucji wpływu politycznego, oddziaływującej na kształt WPZiB. Podstawowym instrumentem wpływu, jak i demokratycznej kontroli PE nad WPZiB są oprócz regularnych debat parlamentarnych odnośnie tej polityki, uchwalane przez ten organ rezolucje. Są to najliczniejsze dokumenty posiedzeń plenarnych Parlamentu, które dzielą się na legislacyjne (dotyczące projektów legislacyjnych) oraz nielegislacyjne - wszystkie pozostałe (Ogonowska, 2006, s. 18).

Parlament próbuje wpływać na kształt i kierunki rozwoju WPZiB przede wszystkim poprzez przyjmowanie rezolucji nielegislacyjnych, które choć pozbawione mocy prawnie wiążącej pozwalają temu organowi wyrazić swoje stanowisko w stosunku do podstawowych kwestii będących przedmiotem WPZiB. Jeszcze przed zawarciem Traktatu Lizbońskiego, PE w wielu rezolucjach postulował rozszerzenie swoich kompetencji odnośnie WPZiB, krytykując zarazem brak wymiaru parlamentarnego tej polityki i poważny deficyt demokracji w procesie decyzyjnym. Zdaniem PE nie można sprowadzać WPZiB do zwyczajnego dodatku do polityk zagranicznych państw członkowskich, dlatego należy umożliwić Unii odgrywanie skuteczniejszej roli na arenie międzynarodowej poprzez nadanie jej osobowości prawnej w celu występowania jako jednolity podmiot w stosunkach zewnętrznych (zob. UE w świecie i granice UE a dobrze prosperujaca Europa bez konfliktów i barier. Stanowisko Parlamentu Europejskiego).

Osiągnięcie większej jedności politycznej w ramach UE było i jest zdaniem PE niezbędne do wzmocnienia i skutecznego funkcjonowania WPZiB. Dlatego PE postulował wzmocnienie komponentu wspólnotowego WPZiB i opowiadał się za szybką ratyfikacją Traktatu z Lizbony, który jak podkreślał wzmacnia zdolność Unii do podejmowania działań na arenie międzynarodowej poprzez utworzenie między innymi urzędu Wysokiego Przedstawiciela Unii ds. Zagranicznych i Polityki Bezpieczeństwa pełniącego równocześnie funkcję wiceprzewodniczącego KE, odpowiedzialnego przed Parlamentem, jak również ustanowienie, za zgodą KE i po zasięgnięciu opinii PE, europejskiej służby działań zewnętrznych (zob. Rezolucja Parlamentu Europejskiego z dnia 5 czerwca 2008 r. w sprawie rocznego sprawozdania Rady dla Parlamentu Europejskiego dotyczacego głównych aspektów i podstawowych wyborów w zakresie $W P Z i B)$.

Dlatego PE z zadowoleniem przyjął wejście w życie Traktatu Lizbońskiego, wyrażając opinię, że połączenie międzyrządowych i wspólnotowych filarów i funkcji w jednym stanowisku wiceprzewodniczącego KE i wysokiego przedstawiciela, zatwierdzanego przez Parlament, może wzmocnić demokratyczną legitymację działań z zakresu WPZiB. 
Parlament podkreślił również, że aby Unia mogła skutecznie realizować swoje cele w środowisku międzynarodowym, promować wartości, jak i interesy potrzebuje spójnej strategii polityki zagranicznej, która powinna jasno określać wspólne interesy bezpieczeństwa UE, stanowiąc zarazem ramy odniesienia dla tworzenia tej polityki, a także formułowania, finansowania, wdrażania i monitorowania unijnych działań zewnętrznych (zob. Rezolucja Parlamentu Europejskiego z dnia 10 marca 2010 r. w sprawie rocznego sprawozdania Rady dla Parlamentu Europejskiego dotyczacego głównych aspektów i podstawowych wyborów w zakresie WPZiB w 2008 r.).

WPZiB w opinii PE powinna skupiać się przede wszystkim na wspieraniu praw człowieka, promowaniu pokoju i bezpieczeństwa w państwach sąsiadujących z Europą i w skali globalnej, wspieraniu multilateralizmu i poszanowania prawa międzynarodowego, zwalczaniu terroryzmu, nierozprzestrzenianiu broni masowego rażenia i rozbrojeniu, przeciwdziałaniu zmianom klimatycznym i zapewnieniu Europie bezpieczeństwa energetycznego (zob. Rezolucja Parlamentu Europejskiego z dnia 19 lutego 2009 w sprawie rocznego sprawozdania Rady dla Parlamentu dotyczqcego głównych aspektów i podstawowych wyborów w zakresie WPZiB w 2007 r.).

Szczególną uwagę PE przywiązuje do kwestii poszanowania praw człowieka i podstawowych wolności. Jest to jeden z najważniejszych celów WPZiB i w opinii PE powinien być absolutnym priorytetem europejskiej polityki zagranicznej. Dlatego PE opowiada się za zwiększeniem zdolności UE do reakcji na łamanie praw człowieka w państwach trzecich i za włączaniem zagadnień z tego zakresu do polityki UE wobec tych krajów. Parlament podkreśla również potrzebę prowadzenia solidarnej i spójnej polityki wszystkich państw członkowskich wobec krajów trzecich, w których dochodzi do częstych przypadków łamania praw człowieka i wzywa by stosunki dwustronne z tymi państwami były zgodne z polityką UE, a szczególnie ze standardem aktywnego zabiegania o przestrzeganie tych praw (zob. Rezolucja Parlamentu Europejskiego z dnia 26 kwietnia 2007 r. w sprawie rocznego sprawozdania z zakresu sytuacji praw czlowieka na świecie w roku 2006 oraz polityki UE w tej dziedzinie).

Przekonanie PE, że działania zewnętrzne UE muszą być inspirowane promocją i ochroną wartości UE takich jak poszanowanie praw człowieka, wolności, demokracji oraz praworządności idzie w parze z krytyką PE wobec dotychczasowej unijnej polityki zagranicznej wobec reżimów autorytarnych, przedkładającej stabilność i bezpieczeństwo nad zasady i wartości, którymi zgodnie z traktatami powinna kierować się w swej polityce UE (zob. Rezolucja Parlamentu Europejskiego z dnia 12 września 2012 r. w sprawie rocznego sprawozdania Rady dla Parlamentu Europejskiego na temat wspólnej polityki zagranicznej $i$ bezpieczeństwa).

Prawa człowieka stanowią jeden z traktatowych celów WPZiB i między innymi dlatego są przedmiotem szczególnego zainteresowania PE. Jednakże Parlament duże znaczenie przywiązuje również do zapewnienia Europie bezpieczeństwa energetycznego, które choć pozbawione podstawy traktatowej winno stać się istotnym składnikiem bezpieczeństwa ogólnego UE. Dla PE wysokie uzależnienie energetyczne UE od krajów, w których panują systemy autorytarne stanowi poważną przeszkodę dla rozwoju skutecznej i spójnej WPZiB oraz utrudnia prowadzenie polityki promującej przestrzeganie praw człowieka. $Z$ tego powodu PE wzywa do rozwoju wspólnej europejskiej polityki zagranicznej w dziedzinie energetyki i włączenia jej do WPZiB poprzez nadanie odpo- 
wiedniej podstawy traktatowej (zob. Rezolucja Parlamentu Europejskiego z dnia 26 września $2007 r$. w sprawie wspólnej europejskiej polityki zagranicznej w dziedzinie energetyki). Dlatego chcąc zwiększyć bezpieczeństwo energetyczne UE i uniezależnić politykę UE od dostaw surowców z krajów o autorytarnych reżimach, PE z jednej strony opowiada się za dywersyfikacją dostawców energii, stworzeniem zintegrowanej europejskiej sieci energetycznej, urzeczywistnieniem wewnętrznego rynku energii, a z drugiej strony optuje za promowaniem odnawialnych, jak i rodzimych źródeł energii (zob. Rezolucja Parlamentu Europejskiego z dnia 11 maja 2011 r. dotyczqca rocznego sprawozdania Rady dla Parlamentu Europejskiego dotyczacego głównych aspektów i podstawowych wyborów w zakresie WPZiB w 2009 r.).

\section{Podsumowanie}

Oceniając rolę PE w procesie kształtowania WPZiB można oczywiście przyjąć założenie, które $\mathrm{z}$ formalno-traktatowego punktu widzenia będzie prawdziwe, że organ ten jest pełnoprawnym podmiotem odpowiadającym za kształt unijnego porządku prawnego, ale w odniesieniu do zagadnień wchodzących w zakres WPZiB jego rola sprowadza się do bycia przede wszystkim instytucją o charakterze opiniodawczym i konsultacyjnym. Jednakże faktyczne znaczenie PE w kształtowaniu WPZiB jest większe niż wynikałoby to z traktatowych unormowań. Parlament Europejski jest jedyną, mającą demokratyczną legitymację instytucją unijną, która z założenia reprezentuje społeczeństwa Europy. Organ ten w swojej działalności może powoływać się na wolę europejskiej opinii publicznej, zarazem ją kształtując dzięki posiadaniu szerokiego spektrum instrumentów oddziaływania (debaty parlamentarne, rezolucje, raporty, zalecenia). Pozwala mu to wpływać poza zakresem swoich traktatowych kompetencji na decyzje Rady UE będącej głównym organem decyzyjnym WPZiB. Jednakże cel jaki stawia sobie PE w dziedzinie WPZiB, a mianowicie jej przekształcenie w kierunku polityki funkcjonującej przede wszystkim w oparciu o mechanizmy współpracy ponadnarodowej i poddanej kontroli parlamentarnej nie został jeszcze osiagnięty. Pomimo wejścia w życie Traktatu Lizbońskiego rola PE w dziedzinie kształtowania WPZiB nie wzrosła tak jak oczekiwałby Parlament. Mimo ujednolicenia stosunków zewnętrznych UE i zlikwidowania jej filarowości, WPZiB pozostała jednak w stosunku do innych obszarów integracji polityką szczególną, której międzyrządowy charakter został utrzymany. Oznacza to, że kompetencje PE w jej kształtowaniu pozostały ograniczone i nie odpowiadają one roli i znaczeniu tego organu w systemie instytucjonalnym UE. Pomimo posiadania przez PE istotnych kompetencji w obszarze dawnej wspólnotowej polityki zagranicznej, wzrost realnych uprawnień PE w dziedzinie WPZiB jest kwestią dalekiej przyszłości. Stanie się przez PE pełnoprawnym w stosunku do Rady Europejskiej i Rady UE organem kształtującym WPZiB wiąże się ściśle z koncepcją ustanowienia ponadnarodowej unii politycznej, w ramach której będzie możliwe prowadzenie polityki zagranicznej poza instytucjami państwa narodowego. W przypadku niezrealizowania tego projektu uwspólnotowienie WPZiB, a co za tym idzie zwiększenie kompetencji unijnych organów ponadnarodowych takich jak PE w kreowaniu tej polityki pozostanie w sferze postulatywnej. 


\section{Bibliografia}

Cini M. (2007), Podejście międzyrzqdowe, w: Unia Europejska-organizacja i funkcjonowanie, (red.) idem, Warszawa.

K. Czubocha, M. Paszkowska, Finansowanie Wspólnej Polityki Zagranicznej i Bezpieczeństwa Unii Europejskiej, http://www.e-finanse.com/artykuly/70.pdf, 24.02.2010.

Deklaracje dołączone do Aktu Końcowego Konferencji Międzyrządowej, która przyjęła Traktat z Lizbony podpisany w dniu 13 grudnia 2007 r., Dz. U. C 83/343 z 30.03.2010.

Jarecki M., Zmiany systemowe wprowadzone przez Traktat z Lizbony, http://www.psz.pl/index.php?option $=$ content\&task=view\&id $=33876,21.09 .2010$.

Kurczewska U., Budżet wspólnej polityki zagranicznej i bezpieczeństwa Unii Europejskiej, 15.02.2005, http://www.pism.pl/biuletyny/files/257.pdf, 14.05.2010.

Łoś-Nowak T. (2005), Wspólna Polityka Zagraniczna i Bezpieczeństwa Unii Europejskiej z perspektywy Polski, „Przegląd Europejski”, nr 1.

Miszczak K. (2008), Reforma Wspólnej Polityki Zagranicznej i Bezpieczeństwa, w: Traktat z Lizbony. Główne reformy ustrojowe Unii Europejskiej, (red.) J. Barcz, UKiE Warszawa.

Ogonowska A. (2006), Dokumenty i publikacje instytucji i organów Unii Europejskiej, „Zeszyty OIDE", nr 6.

Porozumienie międzyinstytucjonalne pomiędzy Parlamentem Europejskim, Radq i Komisja w sprawie dyscypliny budżetowej i należytego zarzqdzania finansami, Dz. U. C 139 z 14.06.2006.

Regulamin Parlamentu Europejskiego, 22.07.2013, www.europarl.europa.eu/sides/getLastRules.do?language $=$ PL\&reference $=$ TOC, 22.09.2013.

Rezolucja Parlamentu Europejskiego z dnia 26 kwietnia 2007 r. w sprawie rocznego sprawozdania z zakresu sytuacji praw człowieka na świecie w roku 2006 oraz polityki UE w tej dziedzinie, 26.04.2007, http://eur-lex.europa.eu/LexUriServ/LexUriServ.do?uri=OJ:C:2008:074E:0753: 0775:PL:PDF, 21.06.2009.

Rezolucja Parlamentu Europejskiego z dnia 26 września 2007 r.w sprawie wspólnej europejskiej polityki zagranicznej $w$ dziedzinie energetyki, 26.09.2007, http://www.europarl.europa.eu/ sides/getDoc.do?pubRef=-//EP//TEXT+TA+P6-TA-2007-0413+0+DOC+XML+V0//PL, 24.09.2009.

Rezolucja Parlamentu Europejskiego z dnia 5 czerwca 2008 r. w sprawie rocznego sprawozdania Rady dla Parlamentu Europejskiego dotyczqcego głównych aspektów i podstawowych wyborów $w$ zakresie WPZiB, 5.06.2008, http://www.europarl.europa.eu/sides/getDoc.do?type= TA\&reference=P6-TA-2008-0254+DOC+XML+VO/P1, 24.09.2009.

Rezolucja Parlamentu Europejskiego z dnia 19 lutego 2009 w sprawie rocznego sprawozdania Rady dla Parlamentu dotyczqcego głównych aspektów i podstawowych wyborów w zakresie WPZiB w 2007 r., Dz. U. C 76 E z 25.03.2010.

Rezolucja Parlamentu Europejskiego z dnia 10 marca 2010 r. w sprawie rocznego sprawozdania Rady dla Parlamentu Europejskiego dotyczqcego głównych aspektów i podstawowych wyborów w zakresie WPZiB w 2008 r., Dz. U. C 349 E z 22.12.2010.

Rezolucja Parlamentu Europejskiego z dnia 11 maja 2011 r. dotyczqca rocznego sprawozdania Rady dla Parlamentu Europejskiego dotyczacego głównych aspektów i podstawowych wyborów w zakresie WPZiB w 2009 r., 11.05.2011, http://www.europarl.europa.eu/sides/getDoc.do?pub$\mathrm{Ref}=-/ / \mathrm{EP} / / \mathrm{TEXT}+\mathrm{TA}+\mathrm{P} 7-\mathrm{TA}-2011-0227+0+\mathrm{DOC}+\mathrm{XML}+\mathrm{VO} / / \mathrm{PL}, 21.07 .2013$.

Rezolucja Parlamentu Europejskiego z dnia 12 września 2012 r. w sprawie rocznego sprawozdania Rady dla Parlamentu Europejskiego na temat wspólnej polityki zagranicznej i bezpieczeń- 
stwa, 12.09.2012, http://www.europarl.europa.eu/sides/getDoc.do?pubRef=-//EP//TEXT+ $\mathrm{TA}+\mathrm{P} 7-\mathrm{TA}-2012-0334+0+\mathrm{DOC}+\mathrm{XML}+\mathrm{VO} / \mathrm{PL}, 21.08 .2013$.

Romaniuk-Całkowska E. (2004), Rola Francji w integracji politycznej Europy Zachodniej, Toruń.

Rozporzqdzenie (WE) nr 1638/2006 Parlamentu Europejskiego i Rady z dnia 24 października 2006 r. określajace przepisy ogólne w sprawie ustanowienia Europejskiego Instrumentu Sasiedztwa i Partnerstwa, Dz. U. L 310 z 9.11.2006.

Ruszkowski J. (2007), Wstęp do studiów europejskich. Zagadnienia teoretyczne i metodologiczne, Warszawa 2007.

Świętochowska U. (2002), Idea integracji europejskiej w cywilizacji przełomu XX i XXI wieku, Gdańsk.

Turczyński P. (2007), Aspekty polityczno-prawne Wspólnej Polityki Zagranicznej i Bezpieczeństwa Unii Europejskiej, „Przegląd Europejski”, nr 1.

UE w świecie i granice UE a dobrze prosperujaca Europa bez konfliktów i barier. Stanowisko Parlamentu Europejskiego, http://www.futureofeurope.europarl.europa.eu/future/webdav/site/myjahiasite/shared/import/Home/EP_PE/chambre1/.../613642PL.pdf, 26.07.2009.

Wersja skonsolidowana Traktatu o Funkcjonowaniu Unii Europejskiej, Dz. U. C 83/144 z 30.03.2010.

Wersja skonsolidowana Traktatu o Unii Europejskiej, Dz. U. C 83/30 z 30.03.2010.

Wiaderny-Bidzińska K. (2002), Polityczna integracja Europy Zachodniej, Toruń.

Wysoki Przedstawiciel Unii do Spraw Zagranicznych i Polityki Bezpieczeństwa, http://europa.eu/legislation_summaries/institutional_affairs/treaties/lisbon_treaty, 14.09.2013.

Zięba R. (2003), Wspólnotowa polityka zagraniczna Unii Europejskiej, „Sprawy Międzynarodowe”, nr 4.

R. Zięba R. (2005), Wspólna Polityka Zagraniczna i Bezpieczeństwa Unii Europejskiej, Warszawa.

The role of the European Parliament in the process of shaping of the Common Foreign and Security Policy after the conclusion of the Treaty of Lisbon.

\section{Streszczenie}

Artykuł porusza problem roli PE w kształtowaniu WPZiB po zmianach dokonanych w tym obszarze integracji przez Traktat Lizboński. Kwestie wchodzące w zakres WPZiB nie należą w przeciwieństwie do zagadnień ekonomicznych do tradycyjnych obszarów integracji, gdyż dotyczą istoty suwerenności państwa narodowego, które ciagle pozostaje najważniejszym aktorem procesu integracji europejskiej. Dominacja międzyrządowych mechanizmów współpracy w ramach WPZiB determinuje ograniczoną rolę PE w kształtowaniu tej polityki. Jednakże należy podkreślić, że PE mimo ograniczonych traktatowych kompetencji w obszarze polityki zagranicznej i bezpieczeństwa stara się w nim odgrywać istotną rolę, często wykraczając poza swoje formalne uprawnienia. Wynika to $\mathrm{z}$ faktu bycia jedyną instytucją unijną mającą demokratyczną legitymację i potrafiącą wpływać na kształtowanie europejskiej opinii publicznej dzięki posiadaniu całego spektrum instrumentów oddziaływania. Na wzrost znaczenia PE w dziedzinie WPZiB wpływa również ustanowienie przez Traktat Lizboński jednolitych stosunków zewnętrznych UE, w których to wielu obszarach PE ma istotne kompetencje. Dalszy rozwój prerogatyw PE w dziedzinie WPZiB jest jednak uzależniony od postępów w procesie przekształcania UE w strukturę o większych kompetencjach ponadnarodowych. 


\section{Summary \\ The role of the European Parliament in the process of developing the EU's Common Foreign and Security Policy after the Lisbon Treaty}

The article discusses the problem of the EP's role in the shaping of the CFSP after the changes made in the area of integration by the Lisbon Treaty. Unlike economic issues, the matters that fall within the scope of the CFSP are not traditional areas of integration, since they deal with the essence of sovereignty of the nation state, which still remains the most important actor of the process of European integration. The dominance of intergovernmental cooperation mechanisms within the CFSP determines the limited role of the PE in shaping the policy. However, it should be noted that despite its limited treaty competence in the area of foreign and security policy, the EP seeks to play a major role, often going beyond its formal powers. This is due to the fact of being the only EU institution with democratic legitimacy, and able to influence the European public opinion with a whole range of instruments of influence it has at its disposal. The growing importance of the EP in the field of CFSP also results from the Lisbon Treaty establishing unified EU external relations, where the EP has significant competence. Further development of the EP's prerogatives in the CFSP is, however, dependent on progress in transforming the EU into a structure of major transnational powers. 
